\title{
Rum, sted, landskab og sport Anglo-nordisk seminar i Keele om nye retninger i
sportsgeografien
}

\author{
af Henning Eichberg
}

Idrættens samfundsmæssige historie besidder meget væsentlige rumlige dimensioner. Dens forløb er bundet til landskabet, bystrukturen og faciliteter. Den placerer aktive og tilskuere rummæssigt overfor hinanden. Den har en territorial - regional, national, international - udbredelse. Og den spiller som kropsligerfaring en rolle for territoriale og nationale identitetsdannelser. Sporten sætter ikke mindst sine spor i miljøet og kan derfor blive genstand for økologisk kritik. Kort sagt: Idræt er et sted (bestemte steder) og udfolder sig i rummet, - place and space.

Dette er indfaldsvinklen for den sportsgeografi, som John Bale fra Keele Universitet i England har udviklet. I flere bøger (Sport and Place, 1982; Sports Geography, 1989; The Brawn Drain, 1991; Sport, Space and the City, 1993) flyttede han i lobet af 1980'erne mere og mere vægten - på bekostningen af geografiens oprindeligt mere naturvidenskabelige og kartografiske træk - i en kritisk-humanistisk retning.

For at gøre status og for at give nye impulser til sit moderfag geografi havde John Bale inviteret til et anglo-nordisk seminar i Keele: Space, Place, Landscape and Sport: New Directions in a Geography of Sport, den 8.-9. juli 1993. 20 forskere fra Danmark, Sverige og Storbritannien mødtes til foredrag og diskussioner, som gerne skulle resultere i en fælles publikation om emnet. Seminaret var sponsoreret af Institute of British Geographers.

Seminaret foregik som et tre-trins-forløb, der førte fra det almene til det konkrete og tilbage til det filosofiske: Globalisering versus regionalisering-case studies om sportens rum - teater og horisont som teoretiske indfaldsvinkler.

\section{Globalisering og \\ regionalisering}

Globaliseringen er et grundlæggende træk i sportens udvikling - og alligevel fyldt med modsigelser. Joe Maguire (Loughborough) illustrerede dette ved kricketspillets placering i opgøret mellem dets gamle moderland England og Australien, der befinder sig politisk og idrætsligt i en afkoblingsproces. En engelsk-australsk kricketmatch i 1992 kunne således udvikle sig til hvad medierne kaldte en „cricket war". - Globaliseringens bagside siden 1970/80'erneer en ny regionalisering, som Henning Eichberg belystebåde for de vesteuropæiske folkeleges og for den østeuropæiske revolutions vedkommende. Modsætningen mellem sportens moderne faglighed og de nye (og gamle) leges feststruktur viser - på tids- og rumkonfigurationernes plan -, at man må regne med et fundamentalt (transmoderne?) skifte. Det festlige spiller en ny rolle - fest som bundet til sted og begivenhed (place and event) $i$ stedet for faglighedens standardisering og homogenisering af rummet (space and progress).

Herefter fulgte nogle case studies: Hvordan tegner sportens billede sig i sted og rum, i byens billede og i landets geografi? Tre forskere fra København havde slået sig sammen i et enestående forsøg på med forskellige metoder og synsvinkler at rekonstruereet idrætssteds kulturøkologi: Idrætsparkens. Jim Toft beskrev Idrætsparkens tidlige tilblivelseshistorie mellem borgerlig byplanlægning, arbejderklassens bevægelsesbehov og socialdemokratisk bypolitik. Stadion'et trådte frem som en demokratisk institution og et folkeligt værested - alt $\mathrm{i}$ alt en historie om varme følelser, socialhistoriens „,varmestrøm". Per Jørgensen tegnede et kontrast- 
billede, støttet på kilder fra de yngste kommunalpolitiske beslutningsprocesser og økonomiske skaktræk, om hvordan Idrætsparken blev til „Parken". Resultatet blev et betonmonument, der lever op til internationale standarder, men næppe kan bruges til folkelig forlystelse - en "kold" historie om planlægning hen over hovedet på folket. Hvordan kan sociologiens diskurs skabe sammenhæng mellem samfundshistoriens „varme" og „kolde" sider? Her fremførte Søren Nagbøl sin dybdehermeneutiske oplevelsesanalyse om - som beboer af Brumleby - at være nabo til Parken og opleve dens „døde skygger". Fotografier viste livets mangfoldige og modsætningsfyldte sider.

Case studies om engelsk fodbold og svensk ishockey belyste andre sider. Alan Burnett (Portsmouth) beskrev de aktuelle politiske stridigheder om at flytte Portsmouth's gamle stadion fra inderbyen til en forstad beboet af det velhavende borgerskab. Hvad sker der, når folkets (og arbejderklassens) forlystelseskultur skal omplantes til et tory-område? Skal befolkningen spørges og hvis så - hvad man har realiseret i Portsmouth -: hvem og hvordan og med hvilke evalueringsmetoder? Hvorfor er der (endnu) så lidt modstand imod flytningen fra fodboldtilhængernes side - og hvordan skal man forholde sig til de nye naboers modvillighed? Problemerne blev endnu mere levende gennem foredragsholderens egen politiske placering. Som lokal labour-leder er Burnett selv ansvarlig for den planlægningspolitiske side - og dog sammen med sin parti-fraktion slet ikke entydig for et ,ja“" eller „nej“ til flytningen.

Atter andre betragtningsmåder kom frem fra de svenske geografers side. Hans Aldskogius (Uppsala) anvendte geografiens klassiske metode - kartograferingen for at synliggøre en svensk top-ishockeyklubs - Leksands IF - lokale, regionale og nationale forankringer. Hvordan fordeler spillerne, de organiserede tilhængere og sponsorerne sig i landet? Hvordan kommer ishockey til at præge billedet af en lille by i Dalarna - sportslig-resultatsmæssigt, businessmæssigt og socialpsykologisk? Og hvor ville det føre hen, hvis klubben engang i fremtiden ikke længere kan opnå sin efter- hånden gennem sammenkøbte spillere udlånte topplacering?

Mere national-historisk skitseredeOlof Moen (Göteborg) ishockeysportens ekspansion som svensk nationalsport, fremmet af teknologiske udviklinger ved facilitetsbyggeriet og af en aggressiv lobby- og anlægspolitik. Hvissporten fortæller nogetom samfundet i det hele taget - hvad betyder så overgangen fra fodboldens og den klassiske socialdemokratis hegemoni i Sverige til ishockey? Den nye nationalsport bygger til forskel fra den tidligere på en klar adskillelse mellem en snævere gruppe af aktive spillere og et bredt forlystelsesorienteret publikum uden egne spilleerfaringer, en kløft mellem produktion og konsumption. Kropsliggør ishockey således 1980’ernes krise i velfærdssystemet og det nye højresving indenfor socialdemokratiet?

\section{Teater og horisont}

Sport som konsumismens nye skuespil hermed var linien trukket tilbage til sportens og geografiens mere teoretiske og til syvende og sidst filosofiske dimensioner. John Bale sammenlignede på glimrende måde sport og teater som to måder at segmentere oplevelsesverdenen på. Og at skabe panoptiske illusionsverdener (i Michel Foucaults forstand - eller omvendt?). På den ene side har det ortodokse - d.v.s. borgerlige, klassisk-moderne - teater med sit stillesiddende publikum og dets ekspertagtige focusering på skuespillets kvalitet været forbilledet for sportens iscenesættelse. Aktuelt kan denne tendens iagttages i det internationale standardiseringspres, som forpligter stadionejerne til udelukkende at tilbyde siddepladser. Et all-seater stadion fastlåser de hidtil bevægelige sport-fans fysisk i række og geled og individualiserer dem. Stik imod det har avantgardeteatret siden århundredets begyndelse tit refereret til sportens tilhængeraktivitet som forebillede for et andet, alternativt teater. Et teater, der skulle overvinde rampen mellem skuespilleren og tilskueren, et amfiteater, hvor folket ser sig selv i ansigtet og hvor tilhængernes sang og karneval aktivt griber ind i atleternes fremvisninger. 
Dette kunne bringe analysen frem til et helt nyt niveau, hvis man tænker analogierne som dog er mere end bare analogier, men fortællinger om modernitetens modsigelsesfulde historie - videre: sport som teater, landskab som teater, samfund som teater. Samfundsteoretiker som Erving Goffman, Guy Debord, Jean Baudrillard og Pierre Bourdieu har peget $i$ lignende retninger. Er teaterantropologien måske oplysende om sportens - og cirkusets - konfigurationer i rum og tid - som levende billeder for samfundets paradigmeskifte? Det ville være en oplagt måde at inddrage Danmarks teateravantgarde, Odin-teatret og Eugenio Barbas internationale teaterantropologiske akademi på.

Hvor teatret forsyner sportens verden med tilskuerpladser, ramper, kulisser (herunder sponsorplakater), opmærksomhedens kropsreguleringer, synets centralperspektiviske kon-centration etc., danner horisonten en anden rumlig-synlig begrænsning. Niels Kayser Nielsen bidrog i Keele med et glimrende eksempel på den originale "the Danish body culture approach". Ved horisonten berører ikke kun himmel og jord (,ånd" og „,støv"), det vertikale og det horisontale, det faste og det glidende hinanden. Men på diskursens plan skærer også det antropologiske (Hvad er horisonten, og hvem er vi som mennesker i grunden?) og det historiske: Hvordan er horisonten for os blevet til den, som den er? "Vores" horisonts historie er modernitetens historie. Den kan bl.a. ses i sammenhæng med svømmekonkurrencens tilblivelseshistorie, som Niels Kayser med nogen dristighed fastslog. Horisonten er både utopiernes, geografiens og sportens moderne markering. Altså ingen transmodernitet?

\section{Hvad idræt og intet andet kan fortælle}

Seminaret end te altså slet ikke der, hvor det var begyndt, men i nye modsigelser. Og alligevel: mindst to „,sikre resultater" kunne tages med hjem.

Det er ikke kun sportsanalysen, der bliver beriget ved den kropslig-rumlige indfaldsvinkel (og dermed potentielt be- kræftet i sin bindestregs-videnskabelige specialisering: sports-geografi på linie med sports-medicin, idræts-historie, sports-psykologi, fodbold-sociologi, ...). Men ved en omvendt betragtning træder den egentlige udfordring frem: Sporten bidrager ved kropslig-rumlige studier til bedre at forstå samfundslivet i dets mangfoldighed, sammenhæng og konfliktstruktur. Det være festens her og nu, horisontens konkrethed og uberørbarhed, socialdemokratiets fodboldog ishockeyarkitektur, sportsteatrets kulisser - altid fortæller idrætten noget, som er af almen betydning - men som kun kan fortælles af idrætten. Boldens rundhed og stadion'ets klang kan aldrig udtømmende oversættes til et sprog af ord. Heller ikke deres samfundsmæssige betydninger kan verbaliseres i deres fulde omfang. Sporten fortæller altid mere om menneskenes sociale kultur, end ord i forvejen påviste.

\section{Placelessness}

Og så det andet: Som led i sportsgeografiens kritisk-humanistiske drejning har John Bale kastet begrebet placelessness ud i debatten. Stikordet stammer fra den kinesisk-amerikanske geograf Yi-Fu Tuan og tilfører geografien en væsentlig kulturkritisk dimension. Placelessness, stedløshed betegner en konkret, kropslig-erfaringsmæssig tilgang til hvad samfundskritikken ellers har betegnet som fremmedgørelse. Sporten gør det synligt: gennem bevægelsens produktgørelse samt medfølgende kvantificering og standardisering skabes en verden af container-rum, hvor intet er tilfældigt eller unikt. Alt skal være genkendeligt og homogeniseret. Stedet forsvinder, hvor rummets funktionelle ensretning tager over.

Dennebetragtningsmåde tilføreridrættens konfigurationssociologi en ny facet. Rum og tid (space and time) har været - og må gerne forblive - et erkendelsesfremmende begrebspar. Det skal imidlertid ses ved siden af parret rum og sted (space and place) med sportens stedløshed som kritisk reference. I begge tilfælde betyder "space“ noget forskelligt. Rum og rum er ikke det samme. Dette kunne suppleres ved at sætte parret rum og mellemrum som en tredje 
binær modsætning, orden og ingenmandsland, eller i det aktuelle sprogbrug: den geometriske orden og den fraktale.

Kan der forventes yderlige antropologisk-epistemologiske differentieringer? Dette antydede geografen Chris Philo (Lampeter/Wales) idet han henviste til semina- rets nok mest alvorlige begrænsning: der varkun mænd med fored rag tilstede. Under disse vilkår er det næppe muligt at nærme sig eller gå i dybden med rummets og stedets (mellemrummets?) kønspolitiske relativitet. 